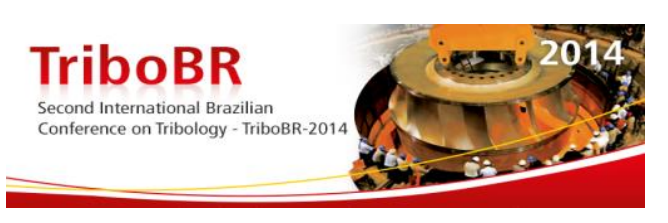

\title{
GREASE LUBRICATION OF GEARS*
}

Johann-Paul Stemplinger ${ }^{1}$ Karsten Stah²

\begin{abstract}
For lubrication of open gear drives applied in rotary furnaces, often gear greases are used as well as for lubrication of gear boxes in difficult sealing conditions. The selection of the gear grease influences strongly the wear behavior. Investigations with flow greases NLGI 00 were made in a back-to-back test rig determining the weight loss due to wear acc. to the standardised procedure ISO 14635 part 3. Different influences like base oil viscosity, thickener type and additional solid lubricant type were analysed. Only the type and amount of solid lubricant shows a significant influence on the weight loss due to wear. Finally, a linear wear coefficient $\mathrm{C}_{\mathrm{IT}}$ according to the calculation method of the wear amount according to Plewe is derived and can be used to transfer the test results to any gears in practice.
\end{abstract}

Keywords: Gears; Lubricant; Grease; Wear.

1 Dr.-Ing., Research Group Manager, FZG - Gear Research Centre, Technische Universitaet Muenchen, Germany.

2 Prof. Dr.-Ing., Head of Institute, FZG - Gear Research Centre, Technische Universitaet Muenchen, Germany.

* Technical contribution to the $2^{\text {nd }}$ International Brazilian Conference on Tribology - TriboBR 2014, November $3^{\text {rd }}$ to $5^{\text {th }}$, 2014, Foz do Iguaçu, PR, Brazil. 


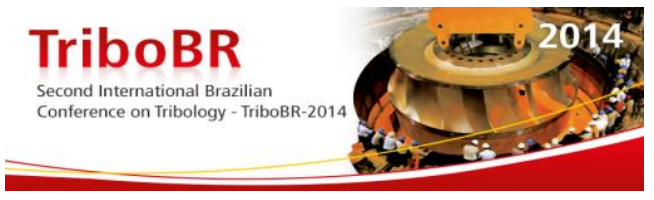

\section{INTRODUCTION}

For lubrication of open gear drives applied in rotary furnaces, often gear greases are used as well as for lubrication of gear boxes in difficult sealing conditions. The selection of the gear grease influences the wear behavior. All presented results are based on the research project DGMK 591 [5] and [4] which was processed by Dr.Ing. Michael Hochmann.

\section{MATERIAL AND METHODS}

\subsection{Test Lubricants}

The investigations of the wear behavior were made for different flow greases NLGI 00 and one base oil. The composition of the flow greases NLGI 00 was varied with regard to the base oil viscosity, to different thickener types and to the addition of different solid lubricants. Mineral oils with an EP additive and without viscosity index improver were used as base oils. The data of the investigated lubricants is shown in Table 1.

Table 1. Data of the investigated lubricants

\begin{tabular}{|c|c|c|c|c|c|c|}
\hline $\begin{array}{l}0 \\
0 \\
0\end{array}$ & 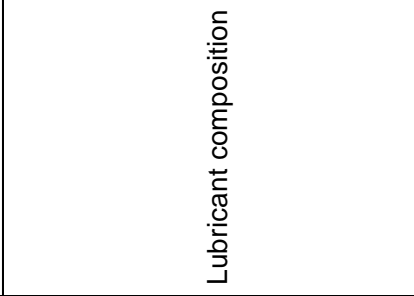 & 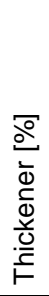 & 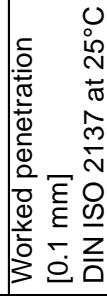 & 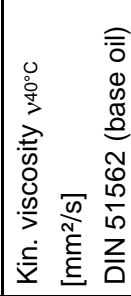 & 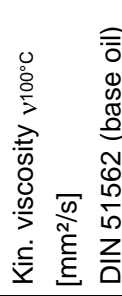 & 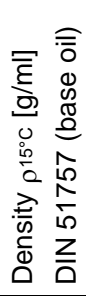 \\
\hline $\mathrm{R}$ & Mineral baseoil + EP & - & - & 638.3 & 35.2 & 0.911 \\
\hline$A$ & $R+A K$ & 3.3 & 410 & 638.3 & 35.2 & 0.911 \\
\hline AV1 & Mineral baseoil + EP + AK & 4.4 & 416 & 72.0 & 8.0 & 0.879 \\
\hline AV2 & Mineral baseoil + EP + AK & 2.6 & 395 & 1241.0 & 54.4 & 0.920 \\
\hline AS & $A+$ add. $R$ & 2.6 & 390 & 638.3 & 35.2 & 0.911 \\
\hline L & $\mathrm{R}+\mathrm{Li}$ & 4.7 & 417 & 638.3 & 35.2 & 0.911 \\
\hline AF1 & $R+A K+F C(4.2 \%, G S<35 \mu m)$ & 2.6 & 408 & 638.3 & 35.2 & 0.911 \\
\hline AF2 & $\mathrm{R}+\mathrm{AK}+\mathrm{FC}(11.1 \%, \mathrm{GS}<35 \mu \mathrm{m})$ & 2.1 & 407 & 638.3 & 35.2 & 0.911 \\
\hline AF3 & $\mathrm{R}+\mathrm{AK}+\mathrm{MD}(4.2 \%, \mathrm{GS}<40 \mu \mathrm{m})$ & 2.6 & 404 & 638.3 & 35.2 & 0.911 \\
\hline \multicolumn{7}{|c|}{ Explanation: } \\
\hline AK & Aluminum complex soap & & & & & \\
\hline $\mathrm{Li}$ & Lithium soap & & & & & \\
\hline EP & Additive RC9505 (4 \%) & & & & & \\
\hline FC & Synthetic graphite & & & & & \\
\hline MD & Molybdenum disulfide & & & & & \\
\hline GS & Grain size for $95 \%$ & & & & & \\
\hline
\end{tabular}

\subsection{Test Equipment - FZG Back-to-Back Gear Test Rig}

The test runs for the determination of the wear behavior of gear greases NLGI 00 were performed on a FZG back-to-back gear test rig. The schematic setup of the FZG back-to-back gear test rig is shown in Figure 1.

\footnotetext{
* Technical contribution to the $2^{\text {nd }}$ International Brazilian Conference on Tribology - TriboBR 2014, November $3^{\text {rd }}$ to $5^{\text {th }}$, 2014, Foz do Iguaçu, PR, Brazil.
} 

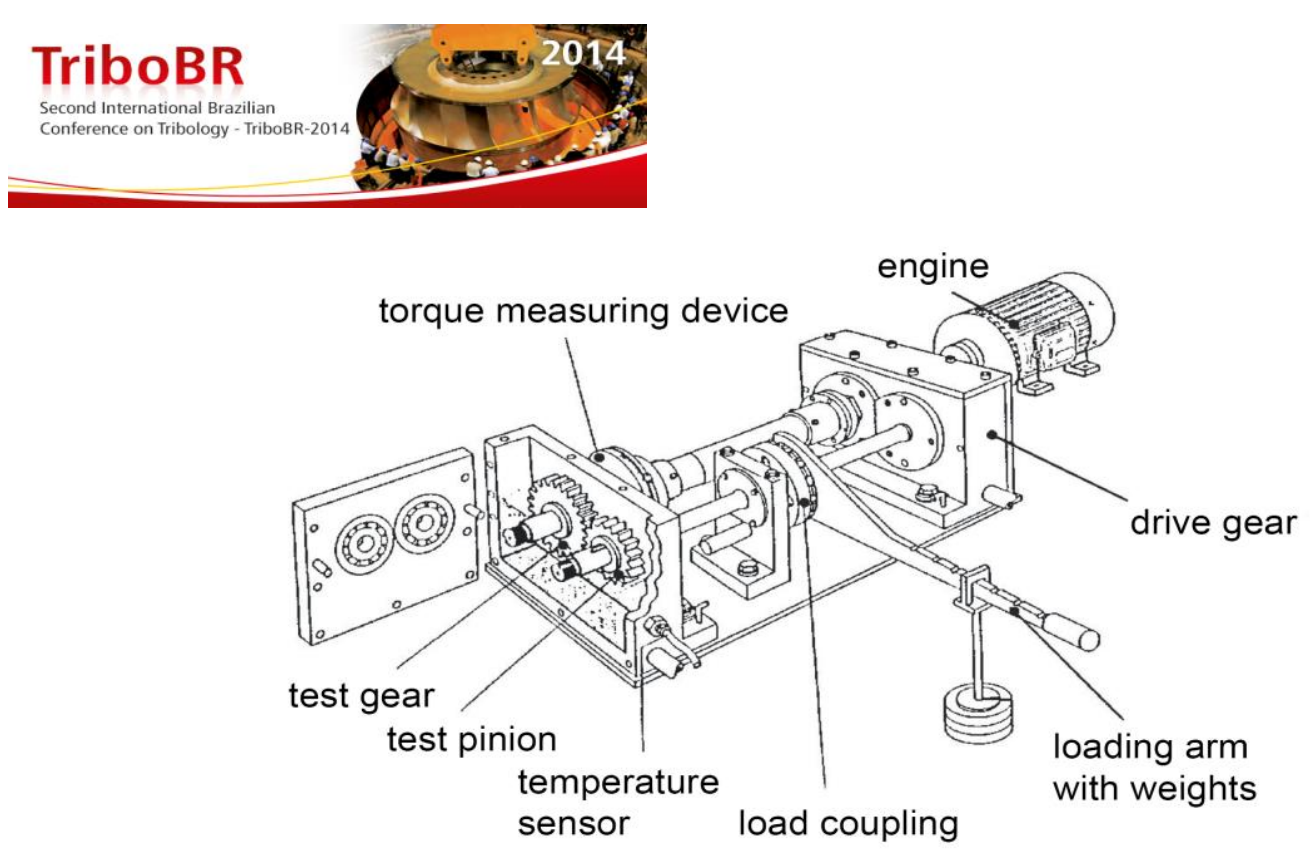

Figure 1. FZG back-to-back gear test rig.

The FZG back-to-back gear test rig utilizes a re-circulating power loop principle, also known as a four-square configuration, in order to provide a fixed torque (load) to a pair of test gears [6]. Test gear box and drive gear box are connected through two torsion shafts. One shaft is divided into two parts and contains a load coupling used to apply the torque (load) through the use of weights hung on the loading arm.

\subsection{Test Gears}

The wear behavior of gear greases NLGI 00 is investigated in the pairing hard-hard of case carburized pinion and wheel. For this purpose the test gears type $A$ are used [6]. The data and manufacturing details of the test gears type $A$ are shown in Table 2.

Table 2. Test gear data

\begin{tabular}{|c|c|c|c|c|}
\hline Dimension & $\left(0, \frac{1}{3}\right.$ & Symbol & $\begin{array}{c}\text { Numerical } \\
\text { value }\end{array}$ & Unit \\
\hline Shaft centre distance & & $\mathrm{a}$ & 91.5 & $\mathrm{~mm}$ \\
\hline Module & & $\mathrm{m}$ & 4.5 & $\mathrm{~mm}$ \\
\hline \multirow{2}{*}{ Number of teeth } & \multirow{2}{*}{$\begin{array}{l}\text { pinion } \\
\text { wheel }\end{array}$} & $z_{1}$ & 16 & - \\
\hline & & $\mathrm{z}_{2}$ & 24 & - \\
\hline Effective tooth width & & $\mathrm{b}$ & 20 & $\mathrm{~mm}$ \\
\hline Helix angle & & $\beta$ & 0 & $\circ$ \\
\hline Pressure angle & & $\alpha$ & 20 & $\circ$ \\
\hline Working pressure angle & & $\alpha_{w}$ & 22.5 & $\circ$ \\
\hline \multirow{2}{*}{ Profile-shift coefficient } & \multirow{2}{*}{$\begin{array}{l}\text { pinion } \\
\text { wheel }\end{array}$} & $x_{1}$ & 0.8532 & - \\
\hline & & $x_{2}$ & -0.50 & - \\
\hline \multirow{2}{*}{ Tip diameter } & \multirow{2}{*}{$\begin{array}{l}\text { pinion } \\
\text { wheel }\end{array}$} & $\mathrm{d}_{\mathrm{a} 1}$ & 88.77 & $\mathrm{~mm}$ \\
\hline & & $\mathrm{d}_{\mathrm{a} 2}$ & 112.50 & $\mathrm{~mm}$ \\
\hline Basic material & & - & $20 \mathrm{MnCr} 5$ & - \\
\hline Surface hardness & & - & $61+/-1$ & $\mathrm{HRC}$ \\
\hline \multirow{2}{*}{ Flank roughness } & \multirow{2}{*}{$\begin{array}{l}\text { pinion } \\
\text { wheel }\end{array}$} & $\mathrm{Ra}$ & $0.35+/-0.10$ & $\mu \mathrm{m}$ \\
\hline & & $\mathrm{Ra}$ & $0.30+/-0.10$ & $\mu \mathrm{m}$ \\
\hline
\end{tabular}

* Technical contribution to the $2^{\text {nd }}$ International Brazilian Conference on Tribology - TriboBR 2014, November $3^{\text {rd }}$ to $5^{\text {th }}$, 2014, Foz do Iguaçu, PR, Brazil. 


\subsection{Test Conditions - Wear Test A/2,8/50}

The tests to analyse the wear behaviour of different gear greases NLGI 00 were made in the wear test $A / 2,8 / 50$ on the basis of ISO 14635-3 [7] and DIN ISO 14635-1 [6] on a FZG back-to-back test rig. In the wear test at dip lubrication the gear type $A$ is used to run at a circumferential speed of $\mathrm{V}_{t}=2.8 \mathrm{~m} / \mathrm{s}$ starting with a step-test and concluding with an endurance test of $100 \mathrm{~h}$ in total. In the step-test the load is rised stepwise starting with loadstage 1 to loadstage 12 with a starting lubricant temperature of $\vartheta \mathrm{s}$, Start $=50{ }^{\circ} \mathrm{C}$ in every loadstage and a limited lubricant temperature of $\vartheta \mathrm{s}=90{ }^{\circ} \mathrm{C}$ in each loadstage. The duration criterion of every loadstage is 21700 load cycles of the wheel, which equals to about 45 min running time. Following the step-test, an endurance test of $100 \mathrm{~h}$ is conducted with a maximum lubricant temperature of $\vartheta$ s, Endurance $=80^{\circ} \mathrm{C}(\mathrm{A} / 2,8 / 80)$. Two tests were made per lubricant for statistical reasons.

\subsection{Analysis}

Based on the results of DGMK 377-01 [3] four different wear categories were defined for the $100 \mathrm{~h}$ endurance test. With these wear categories a classification of the different lubricants can be made due to the wear sum of pinion and wheel, see Table 3. Run-in effects can be eliminated due to the previous step-test.

Table 3. Wear categories for endurance test $100 \mathrm{~h}(\mathrm{~A} / 2,8 / 80)$

\begin{tabular}{|c|c|}
\hline $\begin{array}{c}\text { Wear } \\
\text { category }\end{array}$ & $\begin{array}{c}\text { Wear sum } \\
\text { (pinion+wheel) } \\
{[\mathrm{mg}]}\end{array}$ \\
\hline \hline low & $<70$ \\
\hline medium & $<280$ \\
\hline high & $<700$ \\
\hline very high & $>700$ \\
\hline
\end{tabular}

\section{RESULTS AND DISCUSSION}

\subsection{Test Results}

In total, almost all investigated lubricants, despite the greases with solid lubricants $(A F 1,2,3)$, show low wear in all test parts. Two tests were made per lubricant and the scatter of all results after the endurance test is $< \pm 10 \%$ of the total wear sum. For detailed results of the presented mean values for wear sum see the following Figures 2 - 5. In Table 4 calculated bulk temperatures and film thicknesses of all lubricants can be found for the conditions of the endurance test.

\subsection{Oil vs. Grease}

In Figure 2 an equal wear behavior is shown for baseoil $\mathrm{R}$ and its basegrease $\mathrm{A}$ with a weight loss of under $25 \mathrm{mg}$ after the step-test and under $50 \mathrm{mg}$ after the endurance test. No significant influence of the thickener can be stated.

* Technical contribution to the $2^{\text {nd }}$ International Brazilian Conference on Tribology - TriboBR 2014, November $3^{\text {rd }}$ to $5^{\text {th }}$, 2014, Foz do Iguaçu, PR, Brazil. 


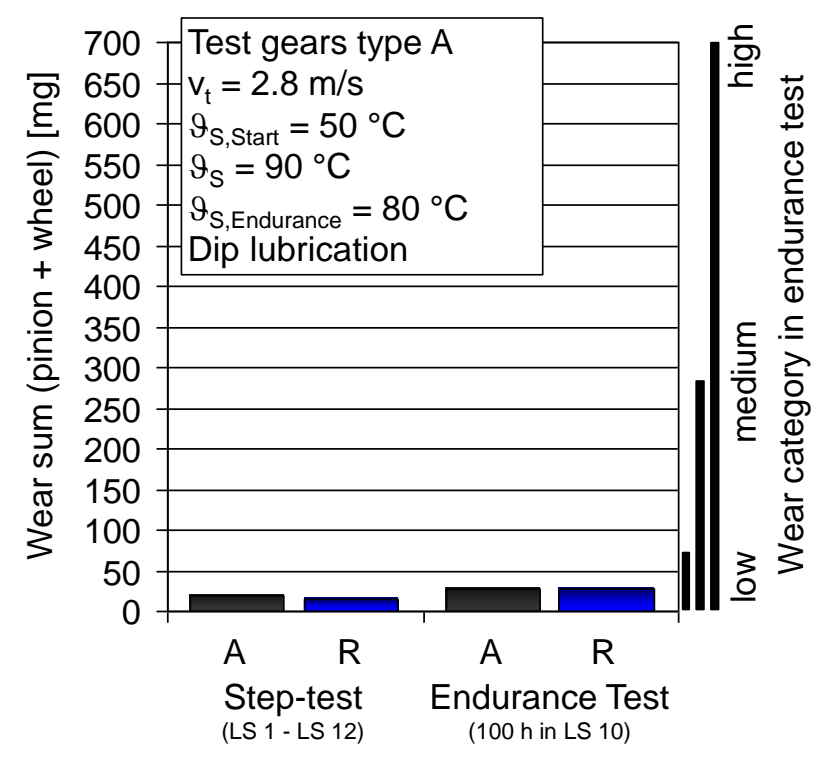

Figure 2. Wear behavior - Oil vs. Grease.

\subsection{Influence of Baseoil Viscosity}

The influence of the baseoil viscosity on the wear behavior of greases in NLGI 00 is shown in Figure 3. Grease A, with its mineral baseoil in ISO VG 680, shows lower wear compared to grease AV1, with its mineral baseoil in ISO VG 68. The grease AV2 with a baseoil viscosity of $v 40=1241 \mathrm{~mm}^{2} / \mathrm{s}$ shows unexpected higher wear, probably due to its mineral baseoil quality. A final reason cannot be seen at this moment. Additional chemical Investigations of the baseoil will be performed. In [10] additional results regarding the viscosity influence of high viscosity fluids and greases NLGI 0 on wear performance are shown. Herein a clear influence of viscosity on wear cannot be seen either.

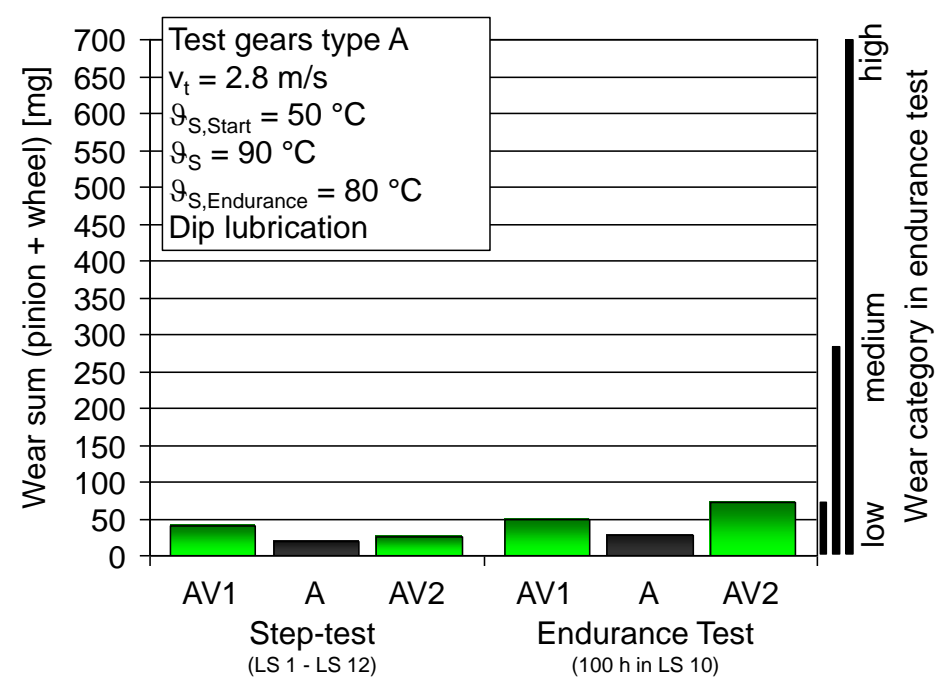

Figure 3. Wear behavior - Influence of baseoil viscosity.

* Technical contribution to the $2^{\text {nd }}$ International Brazilian Conference on Tribology - TriboBR 2014, November $3^{\text {rd }}$ to $5^{\text {th }}$, 2014, Foz do Iguaçu, PR, Brazil. 


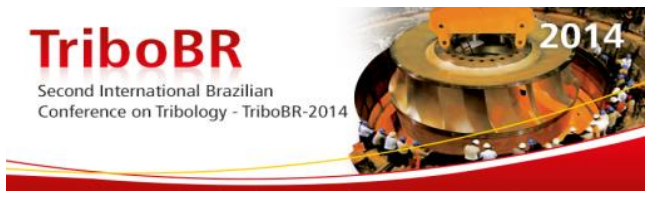

\subsection{Influence of Thickener Type}

The wear behavior of different thickener types for greases in NLGI 00 is shown in Figure 4. The influence of the concentration of thickener in the grease and the type of thickener can hardly be seen. The grease AS is based on basegrease A mixed up with additional base oil R within NLGI grade 00. Grease AS shows slightly higher wear compared to grease A. Grease A with aluminium complex soap shows a slightly higher wear sum compared to grease $L$ with lithium soap.

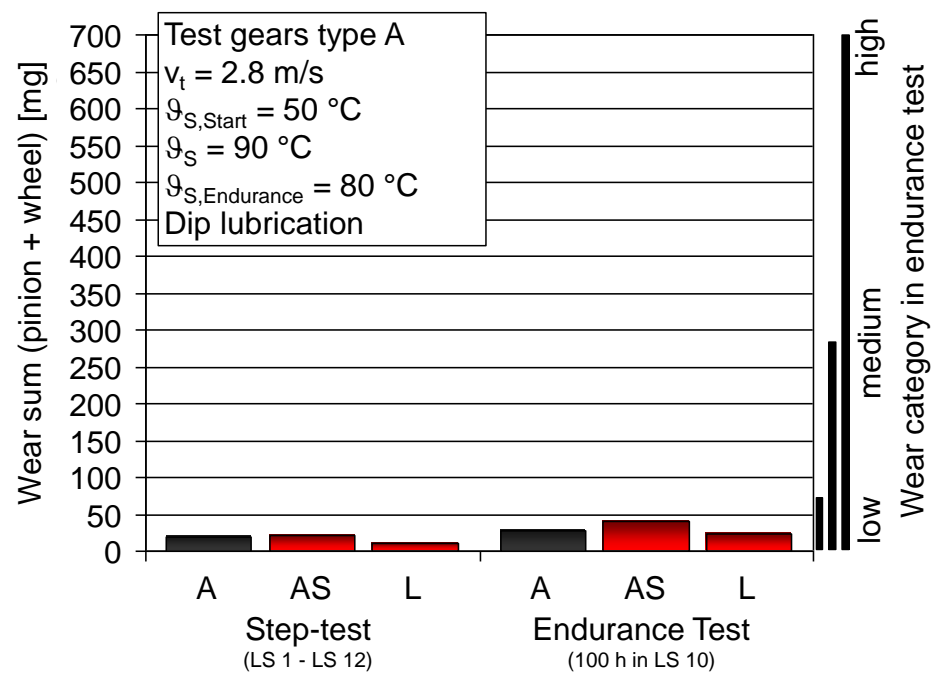

Figure 4. Wear behavior - Influence of thickener type.

\subsection{Influence of Amount and Type of Solid Lubricant}

The influence of the amount and type of additional solid lubricants in greases NLGI 00 on the wear sum of pinion and wheel is shown in Figure 5. Compared to the basegrease A without solid lubricant, AF1 and AF2 show higher wear sums correlating with their concentration of synthetic graphite in the grease, with highest wear for AF2 with a concentration of $11.1 \%$ synthetic graphite. At the end of the steptest AF1 (4.2\% synthetic graphite) shows a three times higher wear sum than the basegrease A and AF2 shows a eight times higher wear sum than the basegrease $A$. This trend is confirmed in the endurance test. The grease AF3, with a concentration $4.2 \%$ of molybdenum disulfide, shows comparable wear to grease A after the steptest and a higher wear after the endurance test. In comparison to the grease AF1 with synthetic graphite, the grease AF3 with molybdenum disulfide shows clearly lower wear.

\footnotetext{
* Technical contribution to the $2^{\text {nd }}$ International Brazilian Conference on Tribology - TriboBR 2014, November $3^{\text {rd }}$ to $5^{\text {th }}, 2014$, Foz do Iguaçu, PR, Brazil.
} 


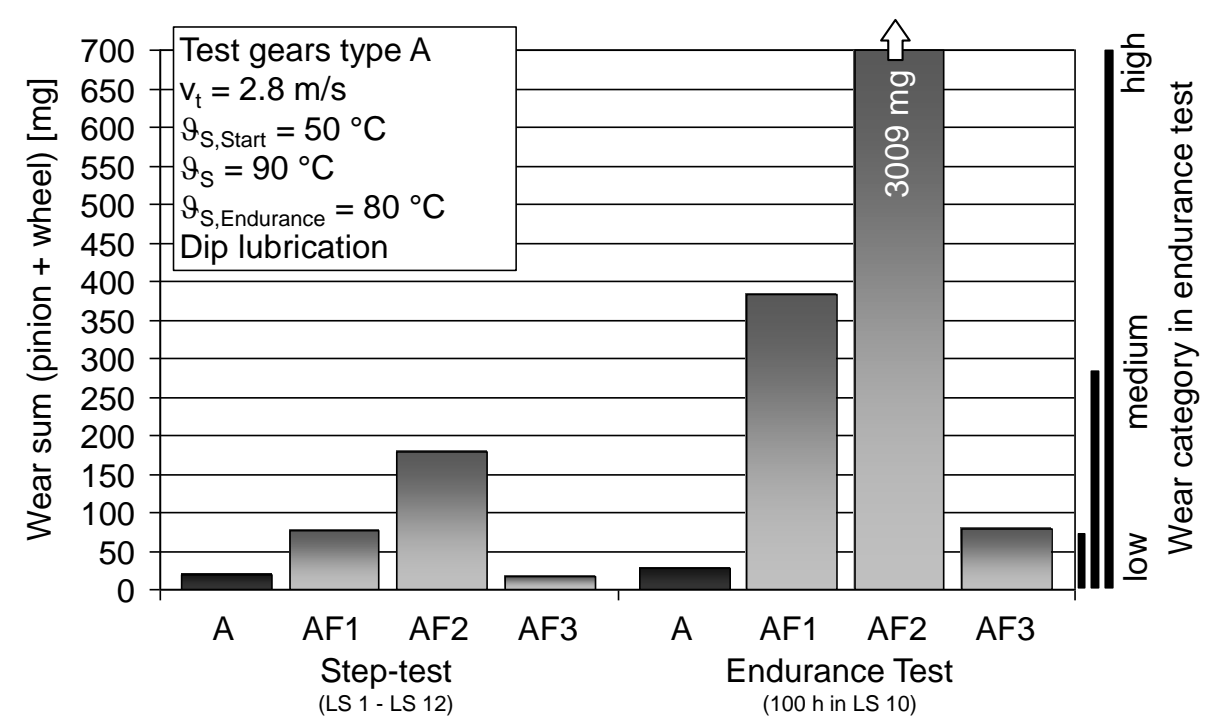

Figure 5. Wear behavior - Influence of amount and type of solid lubricant.

In Table 4 additional calculated values are shown. For each lubricant bulk temperature acc. to Niemann [8] and minimum film thickness acc. to Dowson/Higginson [1] are calculated using the data of each base oil and the operating conditions of the endurance test. No significant difference can be found in the bulk temperature of each lubricant.

Table 4. Bulk temperatures / film thicknesses for endurance test $100 \mathrm{~h}(\mathrm{~A} / 2,8 / 80)$

\begin{tabular}{|c|c|c|c|}
\hline 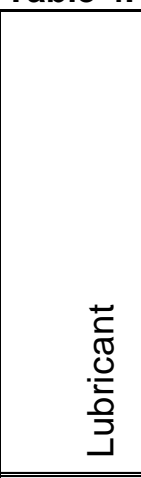 & 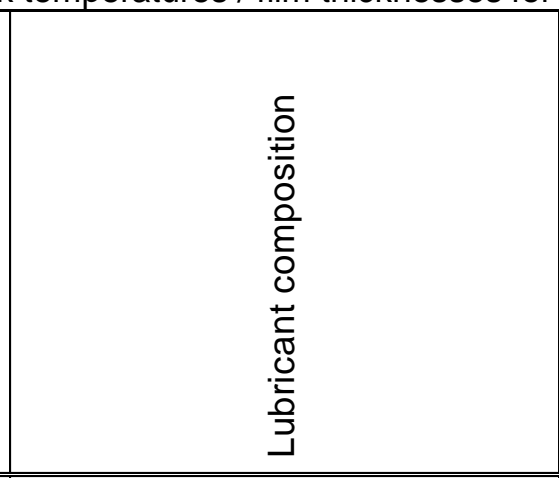 & 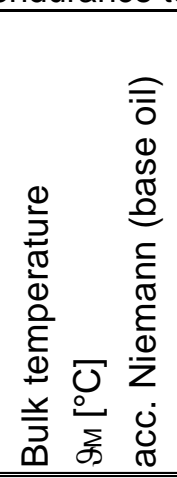 & 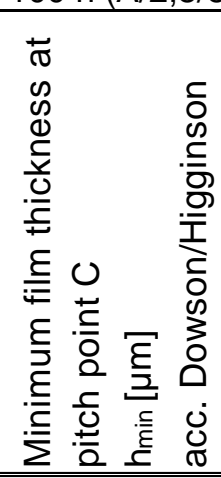 \\
\hline $\mathrm{R}$ & Mineral baseoil + EP & 101.8 & 0.150 \\
\hline A & $\mathrm{R}+\mathrm{AK}$ & 101.8 & 0.150 \\
\hline AV1 & Mineral baseoil + EP + AK & 103.2 & 0.044 \\
\hline AV2 & Mineral baseoil + EP + AK & 101.4 & 0.214 \\
\hline AS & $A+$ add. $R$ & 101.8 & 0.150 \\
\hline $\mathrm{L}$ & $\mathrm{R}+\mathrm{Li}$ & 101.8 & 0.150 \\
\hline AF1 & $\mathrm{R}+\mathrm{AK}+\mathrm{FC}(4.2 \%, \mathrm{GS}<35 \mu \mathrm{m})$ & 101.8 & 0.150 \\
\hline AF2 & $\mathrm{R}+\mathrm{AK}+\mathrm{FC}(11.1 \%, \mathrm{GS}<35 \mu \mathrm{m})$ & 101.8 & 0.150 \\
\hline AF3 & $\mathrm{R}+\mathrm{AK}+\mathrm{MD}(4.2 \%, \mathrm{GS}<40 \mu \mathrm{m})$ & 101.8 & 0.150 \\
\hline
\end{tabular}

\subsection{Wear Calculation}

With these test results candidate lubricants can be discriminated according to their wear characteristics. In addition, it is also interesting to evaluate the actual wear rate to be expected in a gear in practice, if it is operated with the respective lubricant. For

\footnotetext{
* Technical contribution to the $2^{\text {nd }}$ International Brazilian Conference on Tribology - TriboBR 2014, November $3^{\text {rd }}$ to $5^{\text {th }}$, 2014, Foz do Iguaçu, PR, Brazil.
} 
this purpose the test results are introduced into a calculation method acc. to Plewe [9].

\subsection{Wear Calculation acc. to Plewe}

In order to transform the results of the wear test to actual operating conditions in a gear in practice a suitable calculation method was developed by Plewe [9]:

$$
W_{l}=c_{l T} \cdot\left(\frac{\sigma_{H O}}{\sigma_{H O T}}\right)^{I, 4} \cdot\left(\frac{\rho_{C}}{\rho_{C T}}\right) \cdot\left(\frac{\zeta_{W}}{\zeta_{W T}}\right) \cdot N
$$

with

$\begin{array}{lll}W_{\mathrm{I}} & {[\mathrm{mm}]} & \text { linear wear amount } \\ \mathrm{C}_{\mathrm{IT}} & {[\mathrm{mm} / \mathrm{rev}]} & \text { linear wear coefficient from test (Index T) } \\ \sigma \mathrm{HO} & {\left[\mathrm{N} / \mathrm{mm}^{2}\right]} & \text { nominal contact stress } \\ \rho \mathrm{C} & {[\mathrm{mm}]} & \text { relative radius of curvature at pitch point } \\ \zeta_{\mathrm{W}} & {[-]} & \text { wear relevant specific sliding } \\ \mathrm{N} & {[-]} & \text { number of load cycles }\end{array}$

The linear wear amount $W_{\text {। }}$ represents a mean layer thickness of worn out material from the tooth flank.

According to investigations of Plewe [9] the removal of material is not uniform in profile direction of the flank. The maximum wear is expected in the middle between pitch circle and the start of contact and end of contact respectively. The maximum wear depth is about three times the calculated linear wear amount W.

\subsection{Linear Eear Coefficients Cіт of the Investigated Lubricants}

For all candidate lubricants the linear wear coefficient $\mathrm{CIT}_{\mathrm{T}}$ can be calculated from the respective test results according to [8]:

$$
c_{l T}=\frac{c_{m T}}{2 \cdot m_{n} \cdot z \cdot \rho} \quad c_{m T}=\frac{m}{b \cdot N}
$$

\begin{tabular}{|c|c|c|}
\hline $\mathrm{C}_{\mathrm{TT}}$ & {$[\mathrm{mm} / \mathrm{rev}]$} & linear wear coefficient \\
\hline $\mathrm{C}_{\mathrm{mT}}$ & {$[\mathrm{mg} /(\mathrm{mm} \cdot \mathrm{rev})]$} & mass specific wear coefficient \\
\hline$m_{n}$ & {$[\mathrm{~mm}]$} & normal module \\
\hline z & {$[-]$} & number of teeth \\
\hline$\rho$ & {$\left[\mathrm{mg} / \mathrm{mm}^{3}\right]$} & specific gravity of gears \\
\hline $\mathrm{m}$ & [mg] & wear amount \\
\hline b & [mm] & face width \\
\hline $\mathrm{N}$ & {$[-]$} & number of cycles \\
\hline
\end{tabular}

with

To be sure that there is no influence of the run-in, the linear wear coefficient $\mathrm{CIT}_{\mathrm{T}}$ is calculated using the result of the endurance test. For all investigated lubricants the minimum lubricating film thickness $h_{\min }$ was calculated according to Dowson / Higginson [1] based on the baseoil data and the values for the viscosity-pressure coefficients $\alpha$ according to Gold [2]. Due to different load conditions and different gear geometry at the tests of Plewe (index $P$ ) and the wear test $A / 2,8 / 80$ (index $T$ ) a factor $f$ for the linear wear coefficient has to be introduced to get a direct comparability with Plewe.

* Technical contribution to the $2^{\text {nd }}$ International Brazilian Conference on Tribology - TriboBR 2014, November $3^{\text {rd }}$ to $5^{\text {th }}$, 2014, Foz do Iguaçu, PR, Brazil. 
 \\ $f=\left(\frac{\sigma_{H O T}}{\sigma_{H O P}}\right)^{1,4} \cdot\left(\frac{\zeta_{W T}}{\zeta_{W P}}\right)=1.403$}

The calculated linear wear coefficients for the investigated lubricants are introduced in the Plewe-diagram, see Figure 6. Additionally the Plewe wear curves of a straight mineral oil and a grease NLGl 00 without EP-additive are shown for comparison.

The linear wear coefficient $\mathrm{CIT}$ can be taken for the investigated lubricants from Figure 6 introducing the calculated minimum film thickness for the actual transmission at operating conditions to calculate the linear wear amount $\mathrm{W}_{\mathrm{I}}$.

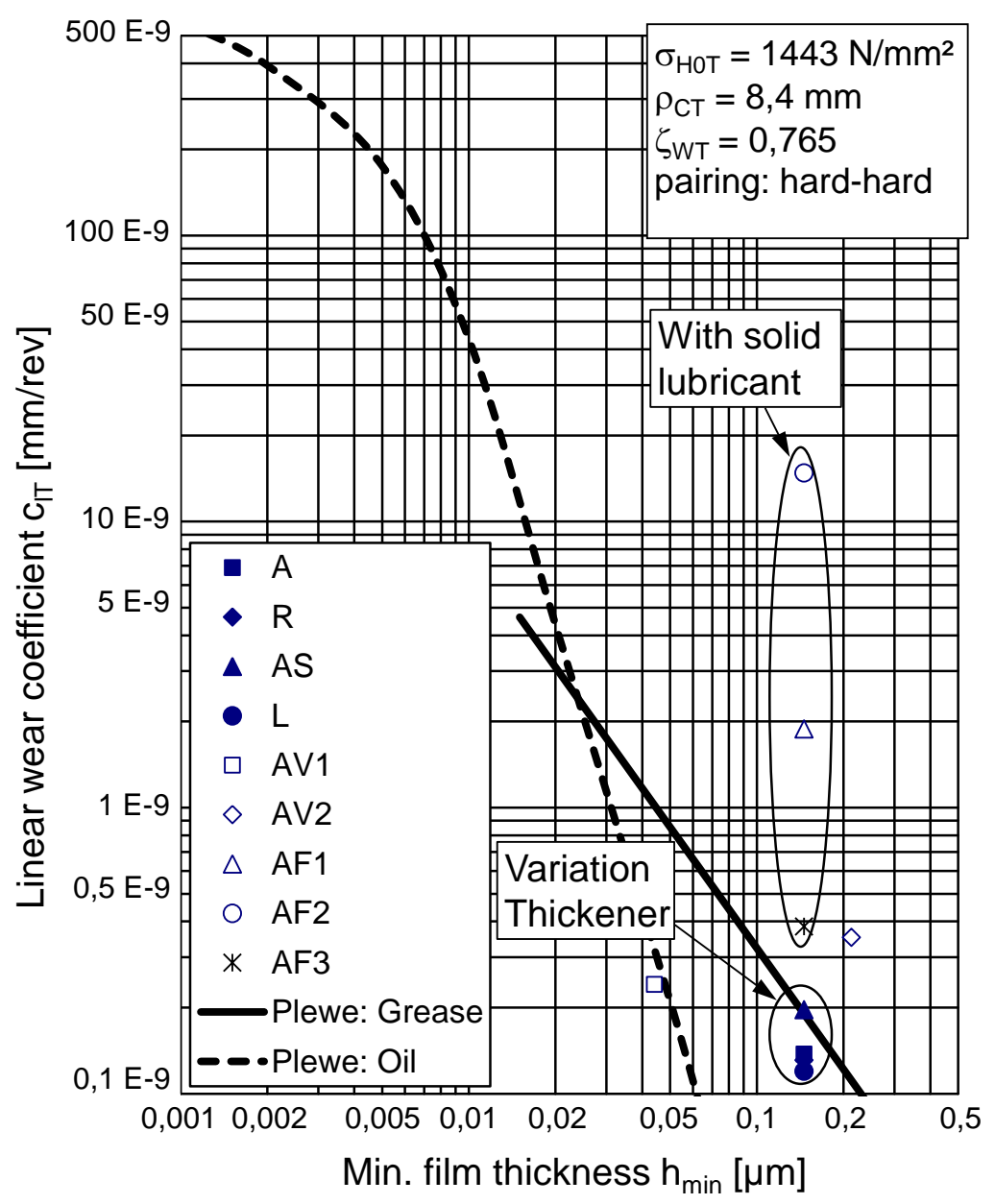

Figure 6. Wear behavior - Linear wear coefficient $\mathrm{C}_{\mathrm{IT}}$.

The wear behavior of the investigated lubricants in ISO VG 680 without solid lubricants correlates well with the Plewe-curve for greases in NLGI 00 with only small changes due to thickener, thickener type and concentration. With additional solid lubricants increasing wear can be detected correlating with the amount of synthetic graphite. With lower baseoil viscosity the grease AV1 shows a lower minimum film thickness and higher wear than the basegrease A with a baseoil viscosity in ISO VG 680. AV2 with the highest kinematic viscosity and highest minimum film thickness shows an unexpected high linear wear coefficient, probably due to its mineral baseoil quality.

\footnotetext{
* Technical contribution to the $2^{\text {nd }}$ International Brazilian Conference on Tribology - TriboBR 2014, November $3^{\text {rd }}$ to $5^{\text {th }}$, 2014, Foz do Iguaçu, PR, Brazil.
} 


\section{CONCLUSION}

Investigations with flow greases NLGI 00 were made in a back-to-back test rig determining the weight loss due to wear acc. to the standardised procedure ISO 14635 part 3. Different influences like base oil viscosity, thickener type and additional solid lubricant type were analysed. Only the type and amount of solid lubricant shows a significant influence on the weight loss due to wear, with highest wear for AF2 with $11.1 \%$ synthetic graphite. Molybdenum disulfide in grease AF3 shows for an equal concentration of $4.2 \%$ lower wear as the synthetic graphite in grease AF1 and slightly higher wear compared to the base grease A without solid lubricant. Finally, a linear wear coefficient $\mathrm{C}_{\mathrm{IT}}$ according to the calculation method of the wear amount according to Plewe is derived and can be used to transfer the test results to any gears in practice.

\section{OUTLOOK}

The knowledge about grease lubricated gear sets is limited worldwide. The institute FZG is going to work on in this field of tribology and tries to minimize this lack of knowledge with different research projects focusing on high viscosity fluids, flow greases NLGI 0 and 00, high consistency greases NLGl 1 and 2, etc., see e.g. [10]

\section{REFERENCES}

1 Dowson D, Higginson GR. Elastohydrodynamic Lubrication, Oxford, 1966

2 Gold PW, Schmidt A, Loos J, Assmann C. Viskosität-Druck-Koeffizienten von mineralischen und synthetischen Schmierölen, Tribologie \& Schmierungstechnik, 48. Jahrgang, 1 / 2001, p. 40 - 48

3 Höhn B.-R, Michaelis K, Bayerdörfer I. Untersuchungen zum Einfluss von Schmier-stoff und Betriebsbedingungen auf das Verschleißverhalten von Zahnrädern, Deutsche Wissenschaftliche Gesellschaft für Erdöl, Erdgas und Kohle e.V., DGMK Forschungsbericht 377-01, Hamburg, 1996

4 Hochmann M. Zahnradtragfähigkeit bei Schmierung mit Getriebefließfetten, Diss. TU München, 2011

5 Hochmann M. Tragfähigkeit von Zahnradpaarungen bei Schmierung mit Getriebefetten, Deutsche Wissenschaftliche Gesellschaft für Erdöl, Erdgas und Kohle e.V., DGMK Forschungsbericht 591, Hamburg, 2007

6 ISO 14635-1: Gears - FZG test procedures - Part 1: FZG test method A/8.3/90 for relative scuffing load-carrying capacity of oils, 2000

7 ISO 14635-3: Gears - FZG test procedures - Part 3: FZG test method A/2,8/50 for relative scuffing load-carrying capacity and wear characteristics of semifluid gear greases, 2005

8 Niemann G, Winter H, Maschinenelemente Band 2: Getriebe allgemein, Zahnradgetriebe - Grundlagen, Stirnradgetriebe, 2. Auflage, Springer Verlag, Berlin, 2003

9 Plewe H.-J. Untersuchungen über den Abriebverschleiß von geschmierten, langsam laufenden Zahnrädern, Diss. TU München, 1980

10 Stemplinger J.-P. Tragfähigkeit und Wirkungsgrad von Stirnradgetrieben bei Schmierung mit hochviskosen Fluiden und Fetten NLGI 0, 1 und 2, Diss. TU München, 2013.

\footnotetext{
* Technical contribution to the $2^{\text {nd }}$ International Brazilian Conference on Tribology - TriboBR 2014, November $3^{\text {rd }}$ to $5^{\text {th }}$, 2014, Foz do Iguaçu, PR, Brazil.
} 